\title{
Diagnostic parameters used in detecting of serious surgical soft tissue infection: Necrotizing fasciitis
}

\author{
Liqaa Shallal Farhan* \\ Maxillofacial Surgery, Dentistry College, Anbar University, Iraq
}

\begin{abstract}
Soft tissue infection in surgery is rapidly progressive infection that caused by variety of bacteria and their exotoxins that ultimately lead to extensive damage and necrosis of deep tissue and fascia. When it occurs in susceptible patients it led to septicemia and septic shock. It occurs mainly in scrotum, pernium and lower limbs and among malnutrition debilitated person. The disease is of high mortality rate. Early identification using is important to unwanted surgical consequence. Aim of study: To focus on the cause and diagnosis of serious soft tissue infection using laboratory investigations. Material and method: The study include (626) patients, (378) male and (248), Age (19-67) years. The study was done in department of General surgery in Al-Ramadi hospital (July 2008-July 2018). Samples of the study was collected from patients come to hospital suffered from Necrotizing fasciitis. These patients undergoing clinical, radiographical examination and laboratory investigations. Samples of tissue are collected for bacterial culture and send to laboratory for bacterial identification and antibiotic sensitivity. X-ray and CT were used for examination of the area. Blood samples were also collected and send to laboratory for complete blood examination. Results: The statistical results indicate that the severe cases is associated with lowest mean value of WBC $(7.1806 \pm 1.95788)$, and lowest mean value of hemoglobin $(6.9260 \pm 2.25653)$ and highest serum level of creatinine (145.9758 \pm 2.33841$)$, glucose $(13.8547 \pm 1.71067)$ and lowest serum sodium (94.0986 \pm .22220$)$ in comparison with control group. The mean difference is significant at 0.05 level $(\mathrm{P}<0.05)$. Conclusion: Necrotising soft tissue infection is a serious fatal condition. Focusing on the cause of such condition of is important to start the early treatment to avoid the mortality.
\end{abstract}

\section{Introduction}

Necrotizing fasciitis is used describe rapidly progressive lifethreatening infection of soft tissue like skin, fat tissue and muscle that spread rapidly and progressive through the tissue space lead to extensive damage to the fasciae. Center of disease control (CDC) found that about 1 million cases detected annually [1]. Necrotizing fasciitis is multibacterial in etiology both anaerobic bacteria like Escherichia Coli, Klebsiella and aerobic bacteria of Group A Streptococci, staphylococcus aureus and some cases caused by fungi. The disease described in culture as "flesh eaten bacteria syndrome" [2,3]. It is commonly affecting the lower part of the body perineum and genital area (Fournier gangrene) and in abdominal wall. It is also following surgical operation in maxillofacial area at $10 \%$ [4]. It is of multibacterial in etiology that act in synergism, that present in the same site mainly by anaerobic bacteria that can grow in low oxygen area and produce gas that full the tissue spaces lead to tissue crepitation and give special appearance in CT and radiograph $[5,6]$. The diagnosis and treatment should be stated immediately because it is life threatening leading to loss of affected limb and serious mortality rate and septicemia [7]. The pathogenesis of the disease is beginning by infection of hypodermis by mutlibacteria that act collectively by release the virulent factor which together with factor released from the host factor leading to this serious infection. This infection is spread rapidly through the soft tissue leading the necrosis by the action of enzyme and exotoxins released by the bacteria $[8,9]$. Poor oxygenation of tissue leads to multiplication of anaerobic microorganisms. The tissue necrosis is caused primarily bacterial destructive enzyme and second by the low blood supply to tissue due to the thrombosis of blood vessels and ischemia caused by the rapidly growing and spreading bacteria in superficial fascia and tissue edema [10,11]. This ischemia makes the infection to disseminated leading to skin necrosis loss of limb within
24 hours [12]. This condition is associated with severe pain when the process involved the regional nerves and lead to tissue anesthesia and paraesthesia. Lymphadenopathy and lymphadenitis is rare due to occlusion of vascular channels [13]. 20 cases with streptococcus shock present with Necrotizing fasciitis. Surgery, trauma, obesity, smoking, IV drug abuse, alcoholism, renal impairment, CVD, malnutrition and bone fracture, Burns, gastrointestinal perforation and low defense among predisposing factors [14].

\section{Material and method}

\section{Sample}

The study includes (626) patients, (378) male and (248) female, Age (19-67) years. The study was done in department of General surgery in Al-Ramadi hospital between (July 2008-July 2018). Sample of the study was collected from patients come to hospital suffered from Necrotizing fasciitis following surgically corrected open fracture of femur and other follow surgical procedure in premium, scrotum and other operation related to lower part of body and patients follow trauma to these areas and data recorded from 2008-2019 from patients come for similar complaint who undergo surgical amputation of lower limb for the same reason. The study sample were grouped according to severity of disease in to following:

${ }^{*}$ Correspondence to: Liqaa Shallal Farhan, M.Sc, B.D.S, Maxillofacial Surgery, Dentistry College, Anbar University, Iraq, E-mail: liqaa.shallal@gmail.com

Key words: necrotizing fasciitis, anaerobic bacteria, Fourniers gangrene, septic shock syndrome, bacterial exotoxins

Received: April 19, 2019; Accepted: May 08, 2019; Published: May 13, 2019 
Group1: Health control with normal value of WBC, $\mathrm{Hb}$, serum glucose and sodium and creatinine.

Group2: Mild cases with WBC $>25 \mathrm{cell} / \mathrm{mm}^{3}, \mathrm{Hb}>13.5 \mathrm{~g} / \mathrm{dl}$, serum glucose $>7 \mathrm{mmol} / \mathrm{l}$, serum sodium $120 \mathrm{mmol} / \mathrm{l}$, creatinine $50 \mathrm{mmol} / \mathrm{l}$.

Group3: Moderate cases with WBC $15-25 \mathrm{cell} / \mathrm{mm}^{3}, \mathrm{Hb} 11-13.5 / \mathrm{dl}$, serum glucose $>11 \mathrm{mmol} / \mathrm{l}$, serum sodium $<110 \mathrm{mmol} / \mathrm{l}$, creatinine $>100$ $\mathrm{mmol} / \mathrm{l}$.

Group4: Severe cases WBC $<15$ cell $/ \mathrm{mm}^{3}, \mathrm{Hb}<11 \mathrm{~g} / \mathrm{dl}$, serum glucose $>14 \mathrm{mmol} / \mathrm{l}$, serum sodium $<94 \mathrm{mmol} / \mathrm{l}$, creatinine $>141$ $\mathrm{mmol} / \mathrm{l}$.

\section{Method}

These patient undergoing clinical examination, radiographical examination and laboratory investigation (blood sample and tissue biopsy). Clinical manifestation of sever soft tissue infection i.e. severe pain, redness and swelling in the area with signs and symptoms of septicemia i.e. fever, malaise, tachycardia and sever hypotension. Samples of tissue were collected for bacterial culture after surgical debridement of the wound for identification of causative bacteria. The tissue sample were placed in sterile saline and send to laboratory using standard technique for bacterial identification and antibiotic sensitivity. $\mathrm{X}$-ray and CT were used for examination of the area. Blood sample was also collected and send to laboratory for complete blood examination including WBC count and differential, $\mathrm{Hb}$, serum creatinin, glucose, sodium.

\section{Statistical results}

The statistical results in Table 1 show the mean value of age, WBC, Hemoglubin, serum glucose, serum sodium, serum creatinine and type of bacteria among the study groups.

\section{Discussion}

Our study is focused on the multimicrobial etiology of serious soft tissue infection "Necrotizing fasciitis". Is an emergency surgical complication that require immediate intervention and treatment to avoid the danger consequence and death due to rapid spreading infection and septic shock. It is commonly affected lower extremities and abdominal wall and pernium. It occurs also in maxillofacial area [15].
The diagnosis of Necrotizing fasciitis is difficult because of absence of specific factors involve in etiology of disease or known portal entry for bacteria [16]. The natural symptom is come into 3 stages: Initial stage, progressive stage and critical stage. Initial stages in 1st (24 hours) with flulike illness and clinically wound site come with severe exaggerated pain and redness and swelling that may by misdiagnose as cellulitis [17]. Progressive stages appear 2-4 days skin become firm, edematous, shiny red and bleeding purpura. The skin become thin with anesthesia because of nerve damage and pressure by gas forming bacteria with fluctuation [18]. Then septic shock within 24 hours with symptom of fever, tachycardia, then hypotension and tachypnea and later on death due to septicemia and progressive tissue damage $[19,20]$. The statistical result of our study in Table 2 show the distribution of study sample and frequency of male (60.1\%) to female (39.6\%).

The statistical result in Table 1 indicate that lowest mean value of WBC count was in severe group was $(7.1806 \pm 1.95788)$ in comparison with control $(\mathrm{P}<0.05)$. The statistical result also indicate that the lowest mean value of Hemoglobin was in severe group was $(6.9260 \pm 2.25653)$ in comparison with mean value of hemoglobin in control group $(\mathrm{P}<0.05)$. Statistical results indicate that the highest mean value of serum glucose was in severe group was $(13.8547 \pm 1.71067)$ in comparison with mean value serum glucose in control group. The results of our study also indicate that lowest mean value of serum sodium level was in severe cases was $(94.0986 \pm .22220)(\mathrm{P}<0.05)$. The statistical results indicate that highest mean value of serum creatinine was in severe group was $(145.9758 \pm 2.33841)$ when compared with control group $(\mathrm{P}<0.05)$. Statistical results in Table 3 and Figure 1 show the distribution of each type of bacteria among the study groups $(\mathrm{P}>0.05)$. History about any trauma surgery related to area, and medical history about comorbidities like: Diabetes, renal disease, etc. [21]. This diagnosis is important to control the disease to improve the quality of life include: Complete blood count with differential, basic metabolite test, Blood Culture. Imaging CT and MRI and ultrasound should be order to role the diagnosis [22]. Using the Laboratory indicator for risk of Necrotizing fasciitis to distinguish Necrotizing fasciitis from other type of soft tissue infection cellulitis. This system involves scoring according $\mathrm{Hb}$ value, WBC count, serum creatinin, glucose, sodium, C-Reactive protein [23]. Once diagnosis is made treatment should be done early to avoid morality by surgical debridement and antibiotic therapy

Table 1. The distribution of study sample

\begin{tabular}{|c|c|c|c|c|}
\hline Study groups & Number & Percent (\%) & Sex & Number \\
\hline Healthy & 13 & 2.1 & Male & 378 \\
\hline Mild & 129 & 21.044 & Female & 248 \\
\hline Moderate & 195 & 31.81 & - & - \\
\hline Severe & 289 & 47.145 & - & - \\
\hline
\end{tabular}

Table 2. Descriptive statistical table

\begin{tabular}{|c|c|c|c|c|c|}
\hline Variables & Healthy & Mild & Moderate & Severe & P-Value \\
\hline Age(years) $\pm \mathrm{SD}$ & $17.4615 \pm 2.87563$ & $27.0388 \pm 2.95910$ & $34.9485 \pm 4.11838$ & $47.4775 \pm 7.60119$ & $<0.05^{*}$ \\
\hline Time of onset(hr) $\pm \mathrm{SD}$ & $0.5077 \pm 0.23879$ & $24.4729 \pm .27379$ & $48.4729 \pm .27979$ & $72.3844 \pm .23096$ & $<0.05^{*}$ \\
\hline $\mathrm{WBC}\left(\mathrm{cell} / \mathrm{mm}^{3}\right) \pm \mathrm{SD}$ & $7496.9615 \pm 3189.92354$ & $34.9922 \pm 9.00911$ & $20.1385 \pm 2.64113$ & $7.1806 \pm 1.95788$ & $<0.05^{*}$ \\
\hline $\operatorname{Hemoglobin}(\mathrm{g} / \mathrm{dl}) \pm \mathrm{SD}$ & $14.3692 \pm 1.62859$ & $13.7163 \pm .139068$ & $12.4815 \pm .951327$ & $6.9260 \pm 2.25653$ & $<0.05^{*}$ \\
\hline $\mathrm{BMI} \pm \mathrm{SD}$ & $20.6923 \pm 1.88788$ & $16.8450 \pm .36335$ & $13.8103 \pm .39311$ & $11.9273 \pm .26004$ & $<0.05^{*}$ \\
\hline Serum glucose $(\mathrm{mmol} / \mathrm{l}) \pm \mathrm{SD}$ & $5.3385 \pm .82314$ & $7.5791 \pm 1.16362$ & $10.3727 \pm .40862$ & $13.8547 \pm 1.71067$ & $<0.05^{*}$ \\
\hline Serum creatinine $(\mathrm{mmol} / \mathrm{l}) \pm \mathrm{SD}$ & $0.9262 \pm .07194$ & $50.3868 \pm 4.40817$ & $100.3902 \pm .63837$ & $145.9758 \pm 2.33841$ & $<0.05^{*}$ \\
\hline Serum $\operatorname{sodium}(\mathrm{mmol} / \mathrm{l}) \pm \mathrm{SD}$ & $146.6923 \pm 4.92248$ & $120.0589 \pm 2.84969$ & $110.4747 \pm 1.20394$ & $94.0986 \pm .22220$ & $<0.05^{*}$ \\
\hline Type of Bacteria & $0.0000 \pm 0.00$ & $3.3023 \pm 1.97881$ & $3.4462 \pm 2.11546$ & $3.8270 \pm 2.17734$ & $<0.05$ \\
\hline
\end{tabular}

*: Highly significant; NS: Non-significant; P-value $<0.05$; SD: Standard deviation; WBC: White blood cell. 
Table 3. The distribution of bacteria type in each study group

\begin{tabular}{|c|c|c|c|c|c|c|c|c|}
\hline & $\begin{array}{l}\text { Staph } \\
\text { aureus }\end{array}$ & $\begin{array}{c}\text { Strep } \\
\text { pyogens }\end{array}$ & $\begin{array}{c}\text { Entero } \\
\text { facecalis }\end{array}$ & E. coli & $\begin{array}{c}\text { Pseudo } \\
\text { aeroginosa }\end{array}$ & $\begin{array}{l}\text { Bacterx } \\
\text { fragilis }\end{array}$ & $\begin{array}{c}\text { Closteridia } \\
\text { Speticum }\end{array}$ & Others \\
\hline Mild count & 30 & 25 & 20 & 19 & 14 & 10 & 8 & 3 \\
\hline Expected count & 26.3 & 22.9 & 20 & 18.3 & 13.5 & 11.6 & 9.7 & 6.7 \\
\hline Moderate count & 45 & 36 & 30 & 25 & 20 & 17 & 13 & 9 \\
\hline Expected count & 39.8 & 34.7 & 30.2 & 27.7 & 20.4 & 17.5 & 14.6 & 10.2 \\
\hline Severe count & 50 & 48 & 45 & 43 & 30 & 28 & 25 & 20 \\
\hline Expected count & 58.9 & 51.4 & 44.8 & 41 & 30.2 & 25.9 & 21.7 & 15.1 \\
\hline Control count & 0 & 0 & 0 & 0 & 0 & 0 & 0 & 0 \\
\hline Expected count & 0 & 0 & 0 & 0 & 0 & 0 & 0 & 0 \\
\hline
\end{tabular}

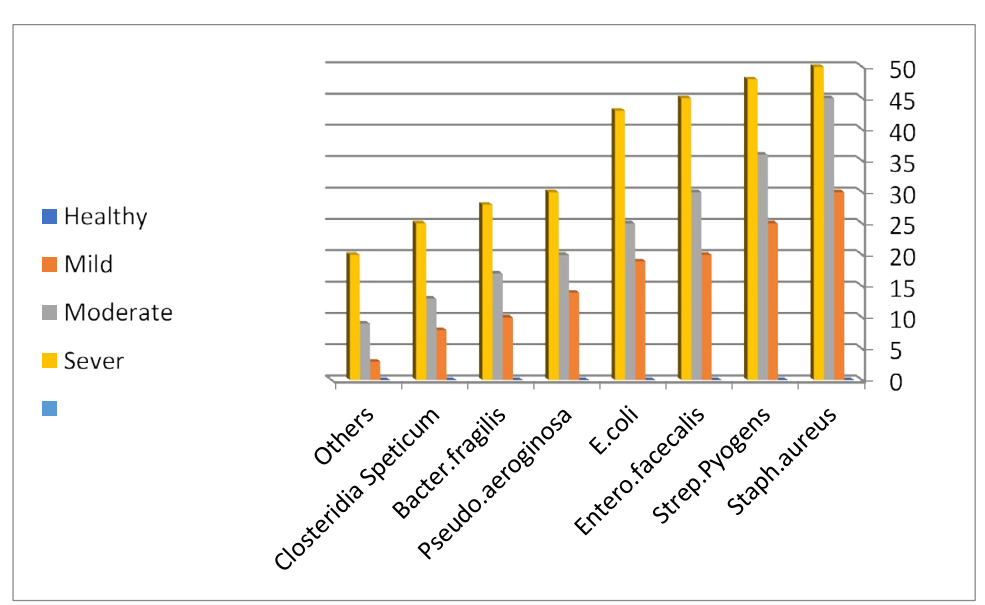

Figure 1. Relation between severity of disease and type of bacteria

\& restoration of hemodynamic status and blood pressure by fluid. Combined antibiotic treatment include Vancomycin plus Carbapenem or ceftrizone or fluroquinolone plus metronidazole [24,25].

\section{Conclusion}

Surgical wound infection is serious complication caused by variety of anaerobic and aerobics bacteria that grow in low oxygen and produce toxins that cause necrosis of deep soft tissue, fascia and fat tissue. It cause also blockage of blood vessels and cause ischemia and later on damage to the organ.

\section{Recommendations}

Knowledge about management and care of surgical wound is important to avoid the danger of serious infection. Immediate identification of dangerous infection and treatment is also important to improve the survival rate.

\section{Acknowledgment}

I would like to send my special thanks and respect to my family and my supervisor in department of surgery who help me to finish my study.

\section{References}

1. Evangelos PM, George B, Paul P, Dimitrios S, Prodromos K, et al. (2014) Concepts in treatment of necrotizing fasciitis. Fort Surg 54: 87-110.

2. Levine EG, Manders SM (2005) Dangerous Necrotizing fasciitis. Clin Dermatol 45: 76-90.

3. Urschel JD, Takita H, Antkowiak JG (2000) Necrotizing soft tissue of chest wall. Ann Thorac Surg 77: 87-109.

4. Kaafarani HM, King DR (2014) Necrotizing skin and soft tissue infections. Surg Clin North Am 99: 200-389.
5. Descamps V, Atiken J, Lee MG (2002) Hippocartes on Necrotizing fasciitis. Lancet 411: 365-5987.

6. Anaya DA, McMahon K, Nathens AB, Sullivan SR, Foy H, et al. (2005) Predictors of mortality and limb loss in necrotizing soft tissue infections. Arch Surg 140: 151-157. [Crossref]

7. Anaya DA, Dellinger EP (2007) Necrotizing soft tissue infection. Clin Infect Disease 88: 45-78.

8. Eke N (2007) Fournier s gangrenes. Br J Surg 5: 88-119.

9. Adam DB, Robert Z, Eliza HC (2014) Necrotizing fasciitis: Diagnosis and management Emergency Medicine 76: 65-87.

10. Anaya DA, Dellinger EP (2007) Mangement Necrotizing tissue infection. $J$ Ophth 44 127-144.

11. Anton H (2018) Treatment of Necrotizing fasciitis. Advanced Emergency Care 44: 7889.

12. Bernnan MR, LeFervre F (2019) Diagnosis of fasciitis infection. Critical Care 16: 10 19.

13. Lin TY, Ou CH, Tzai TS (2014) Amplification of Fournier's gangrene severity index. Int $J$ Urol 36: 66-87.

14. Wong CH, Khin LW, Heng KS, Tan KC, Low CO (2004) Laboratory risk indicator for Necrotizing infection. Crit Care Med 22: 1376-1387.

15. Borschitz T, Schlicht S, Siegel E, Hanke E, Von SE (2015) Improvement in clinical score of Necrotizing fasciitis severe. PLoS One 15: 167-178.

16. Fustes MA, Gutierrez CP, Tamayo SL, Ruiz MR (2002) Necrotising fasciitis: A report of 39 pediatric patients. Arch Dermatol 12: 156-166.

17. Holmstorm B, Grimsley EW (2000) Necrotizing fasciitis and toxic shock syndrome. South Med J 44: 55-78.

18. DeBoer SL, Zeglin D (2001) Necrotising fasciitis mortality rate $45 \%$. American Journal of Nurse 23: 45-89.

19. Korhan T, Hakan Y (2007) Stratigies for diagnosis and management. World Journal for Emergency Surgery 23: 56-98. 
20. Catena F, La DM, Ansaloni L, Argusti S, Taffurelli M (2004) Necrotizing fasciitis: An emergency surgicay. Eur J Med 33: 77-99.

21. Childers BJ, Potyondy LD, Nachreiner R, Roger ER (2002) Necrotizing fasciitis: Retrospective study. Am Surg 22: 67-98.

22. Zdravko R, Zeljka R, Dario M, Davor L (2011) Necrotizng fasciitis:Review of literature. World Journal of Emergency Surgery 33: 143-220.
23. Morgan MS (2010) Approach in diagnosis of Necrotizing fasciitis. J Host Infec 88: $55-98$

24. Cai Y, Gan Y, Yu C, Tang J, Sun Y (2018) The success of treatment of Necrotizing fasciitis after surgery. Medicine 54: 145-260.

25. Bellapianta JM, Ljungquist K, Tobin E (2009) Necrotizing fasciitis. J am Acad Otho Ped Surg 44: 77-98.

Copyright: O2019 Farhan LS. This is an open-access article distributed under the terms of the Creative Commons Attribution License, which permits unrestricted use, distribution, and reproduction in any medium, provided the original author and source are credited. 